\title{
DA LEGITIMIDADE DO ATIVISMO JUDICIAL NA FAMÍLIA HOMOAFETIVA A PARTIR DA AÇÃO DIREITA DE INCONSTITUCIONALIDADE 4.277/2011
}

\section{THE LEGITIMACY OF JUDICIAL ACTIVISM IN THE HOMAFFATIVE FAMILY FROM DIRECT ACTION OF UNCONSTITUTIONALITY}

\subsection{7/2011}

\section{VALÉRIA SILVA GALDINO}

Pós-doutora em Direito pela Universidade de Lisboa; Doutora e mestre em Direito das Relações Sociais pela Pontifícia Universidade Católica de São Paulo (PUCSP); Docente da Universidade Estadual de Maringá e no Programa de Pós-graduação em Ciências Jurídicas pelo Centro Universitário de Maringá (Unicesumar); Pesquisadora pelo ICETI; Advogada no Paraná; E-mail: valeria@galdino.adv.br.

\section{CAIO EDUARDO COSTA CAZELATTO}

Mestre em Ciências Jurídicas pelo Centro Universitário de Maringá (Unicesumar); Bacharel em Direito pela Universidade Estadual de Maringá (UEM); Membro do Centro de Investigação Jurídico-Económica (CIJE) da Faculdade de Direito da Universidade do Porto (FDUP); Advogado no Paraná; E-mail: caio.cazelatto@hotmail.com.

\section{LUIZ AUGUSTO RUFFO}

Membro do Núcleo de Estudos Constitucionais NEC/UEM; E-mail: luizaugusto1919@gmail.com. 


\section{RESUMO}

Realiza-se um questionamento acerca da legitimidade da decisão cometida pelo Supremo Tribunal Federal, resultante da divisão de competências entre os poderes da União. A metodologia utilizada foi a de investigação bibliográfica, tendo base nas críticas levantadas por Lênio Streck sobre a atuação do Poder Judiciário, caracterizando-a como um ativismo judicial a ser combatido, fazendo-se uma reflexão sobre as motivações concretas que fazem o ativismo vir a ocorrer, utilizando-se das considerações de Rachel Nigro, que propõe uma revisão dos conceitos de democracia, fazendo defesa de um ativismo legítimo e necessário. Sendo assim, reconhece-se as negativas do ativismo judicial, mas também se reconhece as negativas da não tutela dos direitos fundamentais em nome de uma aplicação restrita do texto constitucional. Isso, pois, deixar as famílias homoafetivas à margem daquilo que the é de Direito, esperando a boa vontade legislativa, vai contra ao que é, de fato, democrático e constitucional. Pontua-se, ainda, da carga simbólica que uma produção normativa coerente aos aspectos fáticos das famílias homoafetivas traria para efetivar a seguridade jurídica e social de tal grupo.

PALAVRAS-CHAVE: Ativismo Judicial; Direitos Fundamentais; União Homoafetiva.

\section{ABSTRACT}

A questioning about the legitimacy of the decision made by the Federal Supreme Court, resulting from the division of competences between the powers of the Union, was carried out. The methodology used was that of bibliographic research, based on the criticisms raised by Lênio Streck about the performance of the Judiciary, characterizing it as a judicial activism to be fought, reflecting on the concrete motivations that make the activism come to take place, using the considerations of Rachel Nigro, who proposes a revision of the concepts of democracy, making defense of legitimate and necessary activism. thus, it acknowledges the negatives of judicial activism, but also acknowledges the denials of non-protection of Fundamental Rights in the name of a restricted application of the constitutional text. this, therefore, leaving homoaffective families to the margin of what is their right, waiting for legislative 
goodwill, goes against what is, in fact, democratic and constitutional. the symbolic burden that a coherent normative production of the factual aspects of homoaffective families would bring to the juridical and social security of such a group is also punctuated.

KEYWORDS: Judicial Activism; Fundamental rights; Homoaffective Union.

\section{INTRODUÇÃO}

As transformações das tendências que orientam a sociedade exigem que as normas jurídicas que definam o comportamento humano não sejam estáticas, isto é, que se moldem em conformidade com o contexto social ao qual estão inseridas. $A$ busca por essa flexibilidade ganhou destaque a partir da segunda metade do século $X X$, com a consolidação do Estado Social, momento em se ampliou a interferência estatal na vida privada, na tentativa de promover melhores condições aos indivíduos.

O processo histórico evolutivo advindo das Revoluções Industrial e Francesa modificaram e acrescentaram novas concepções de produção, de tecnologia e de princípios éticos, jurídicos e morais, como a liberdade, a igualdade e a fraternidade. Fatores, estes, que impulsionaram a desconstrução de antigos paradigmas na seara das Ciências Jurídicas, principalmente aqueles que se relacionavam com a organização da família.

No Brasil, essas alterações axiológicas ocorreram no Direito das Famílias a partir da Constituição Federal de 1988, a qual afastou a essência individualista, patrimonialista, patriarcal, tradicional e conservadora-elitista que permeavam as codificações civilistas, dando espaço a uma tutela mais abrangente, universal, humanitária e direcionada, sobretudo, à garantia da dignidade da pessoa humana, findando a rígida separação existente entre o público e o privado.

A dinâmica e a complexidade das instituições sociais e dos institutos jurídicos contemporâneos, como a família, o casamento, a filiação, a união estável, o divórcio, a adoção, o planejamento familiar, a utilização das técnicas biomédicas no projeto 
parental, dentre outros, desencadearam novos status, valores e funções à configuração familiar.

Isso só foi viável em virtude da centralização jurídica à subjetividade, que direcionou, sob a influência da doutrina eudemonista, os interesses do sujeito, inclusive os de caráter familiarista, para o alcance da sua realização pessoal, da sua felicidade e do pleno desenvolvimento de sua personalidade, frente aos ultrapassados dogmas que permeavam as ordens social, econômica, moral, política e religiosa. Em outras palavras, não é o ser humano que existe para a família e para o matrimônio, mas a família e o matrimônio que existem para a sua evolução pessoal.

Os ramos do Direito começam a ser "repersonalizados", oportunidade em que o ser humano foi valorizado como o centro da ordem jurídica. Os fundamentos e objetivos patrimoniais e contratuais do Direito Civil passaram a ser orientados por um maior respeito aos direitos fundamentais, buscando garantir a proteção e a promoção das individualidades e da liberdade volitiva de cada pessoa.

Foi nesse cenário que o texto constitucional de 1988 adotou um capítulo próprio dedicado à família, o qual ampliou tanto a conceituação quanto os fundamentos jurídicos dessa instituição, como é possível verificar no art. 226 e seguintes, os quais elencam novas modalidades familiares para além do matrimônio, como a advinda da união estável, bem como a constituída por um dos genitores e seu(s) descendente(s), também denominada por monoparental.

Este é um rol não taxativo, isto é, meramente exemplificativo e inclusivo, permitindo, por consequência, a sua interpretação extensiva, de maneira a incluir os demais arranjos familiares implícitos no ordenamento jurídico. Isso porque, ao abolir a expressão "constituída pelo casamento", do art. 175, da Constituição Federal de 1967, sem substituí-la por outra, a Constituição Cidadã posicionou a família, seja esta qual for, sob a proteção do Estado, afastando a cláusula de exclusão dos modelos familiares

Em que pese se tratar da célula mais básica e duradoura do organismo social, representando o centro da preservação do ser humano e atuando como um espaço político, verifica-se forte resistência de grupos majoritários, bem como do legislativo brasileiro em tutelar e reconhecer todas as configurações familiares que, de fato, 
existem e são vividas no cotidianos dos brasileiros, como se dá com as famílias homoafetivas.

Fazer parte de um grupo socialmente vulnerável implica estar em constante luta pela conquista de direitos ou, ainda, pela manutenção dessas conquistas frente às ameaças provocadas por determinados grupos que negam a legitimidade desses direitos. Por vezes, os direitos que são fundamentais para uma vivência plena são negados a um grupo de pessoas por meio de justificativas religiosas e morais que extrapolam a esfera particular e intimista. Por consequência, essas concepções fundamentalistas atingem a esfera pública, por onde podem provocar uma marginalização legalmente legitimada, mas à qual deve ser resistida e superada para que o Estado Democrático de Direito possa ser consagrado.

De forma simplista, é isso que ocorreu e vem ocorrendo com a temática do casamento entre indivíduos homossexuais. Pode-se verificar que a superação dos estigmas históricos é produto de luta não só frente a sociedade, mas também frente ao Direito, especificamente perante as instituições que o representam: o judiciário e o legislativo.

O objetivo posto por essa pesquisa é realizar um estudo acerca da Ação Direta de Inconstitucionalidade (ADIn.) 4.277 e sua legitimidade em meio às Estruturas Políticas brasileiras. Brevemente, são pontuados alguns momentos históricos que cristalizaram a subordinação dos sujeitos homossexuais às normativas heterossexistas. Fez-se um percurso com destino às novas concepções do Direito de família, as quais são fundadas na dinâmica social a fim de abarcar os novos e emergentes tipos de família. A partir disso, constatou-se que o Poder Constituinte, ao criar o instituto da União Estável e ao reconhecer a família monogâmica em 88, fez jus a representação dos corpos sociais da época.

Quanto à ADIn. 4.722, é feita uma descrição da decisão em sua complexidade interpretativa, sendo pontuadas as argumentações postas, entre elas a interpretação do art. 1.723 do Código Civil conforme os art. $2^{\circ}$ e $5^{\circ}$ da Constituição Federal e um entendimento não restritivo sobre o conceito de "união estável entre homem e mulher" do art. 226 desta.

É traçado, do mesmo modo, uma discussão entre ativismo judicial e judicialização com base em Luís Roberto Barroso e Lênio Streck. São postuladas as 
motivações que acarretam na busca ao judiciário na resolução de matérias políticas e efetivação de demandas sociais. Uma dessas motivações é a crise de representatividade do poder legislativo, motivada por parlamentares que fazer jus a interesses particulares, deixando um vácuo legislativo em determinadas matérias para manterem seu capital político. Isso leva os juízes a se aproveitarem da estrutura analítica da Constituição para contemplar juridicamente as demandas que foram omitidas.

Apesar disso, mesmo sendo uma via de consagração dos anseios populares nos dias atuais, principalmente utilizada por grupos minoritários, a atuação irrestrita e integral da via judicial, considerada contra majoritária, tem sofrido diversas críticas por ser vista como uma ameaça à Democracia, principalmente pela utilização de termos genéricos e fluidos em conceitos, sem real conteúdo delimitado, usados para conferir uma "roupagem" legitimadora ao invés de, fundadamente, delimitar racionalmente os argumentos. Ainda, é pontuado por Streck que apoiar essa postura do Judiciário é segurar uma faca de dois cumes, visto as experiências históricas onde não se pode prever, ou seja, se um ativismo será feito para o bem ou para o mal da sociedade.

Sabe-se, ademais, de acordo com Luís Roberto Barroso (2012), dos fundamentos normativos e filosóficos da atuação contra majoritária do Judiciário em uma Democracia Constitucional, que limitam a discricionariedade subjetiva do magistrado, podendo estes fazerem jus aos direitos de minorias que são abafados pelas demandas da maioria, de forma fundamentada e constitucional.

Considera-se, no entanto, que a crítica perante o Ativismo Judicial tem importância notória, principalmente ao constatar a crise política e representativa do País não só no Poder Legislativo, mas também no judiciário. Contudo, nesta pesquisa busca-se negar que uma atuação ativista das cortes auxiliaria no aprofundamento dessa crise, principalmente quando a decisão é feita de forma coerente e fundamentada na consagração da justiça.

Faz-se, defeso, então, do pressuposto de que a decisão foi necessária para tutelar os Direitos Fundamentais em caráter imediato da população homoafetiva, sendo necessário evocar ainda assim um diálogo nas esferas políticas para conferir seriedade e comprovar a pacificação da matéria no âmbito formal e social. 
A metodologia empregada compreenderá na investigação bibliográfica, que consiste em analisar, de forma crítica, o que já foi produzido e registrado acerca do tema em obras doutrinárias, periódicos, legislação, reportagens e documentos eletrônicos. Além disso, mediante as premissas elencadas por meio da investigação bibliográfica, utiliza-se do método dedutivo para a elaboração de conclusões pertinentes à problemática.

\section{UNIÃO ESTÁVEL E FAMÍLIA HOMOAFETIVA}

O preconceito que afeta diariamente a população homossexual é produto de um percurso histórico iniciado desde os primórdios da civilização. Com a queda do Império Romano e a propagação dos ideais cristãos, fundados nas passagens bíblicas, o Código Justiniano de 533 d.C proibiu categoricamente a intimidade entre pessoas do mesmo sexo à nível do adultério e divórcio. Nos reinos bárbaros constituídos pela desintegração do Império Romano do Ocidente, havia uma tolerância relativa quanto ao que era denominado como "sodomia", mas se tornou intolerável com a solidificação do Cristianismo, a partir do processo inquisitivo e com o III Concílio de Latrão (1179). ${ }^{1}$

Foi a partir do século XIII que começaram a ser criadas leis seculares em conjunto com o aparato dogmático cristão que criminalizavam a homossexualidade nos territórios ocidentais. Já na Modernidade, a marginalização e violação dos homossexuais deslocou-se da categoria de "heresia" para a categoria da "perversão", desenvolvida posteriormente, no século XX, pela ideia de que o "homossexualismo" era uma patologia. Os estudos difundidos quanto a isso foram cometidos pelos campos da medicina e psicologia, primordialmente, sendo que até mesmo a lobotomia ${ }^{2}$ era praticada contra os considerados "depravados". Ser gay, então, era ser doente (ESKRIDGE JUNIOR, 1993; PICKETT, 2002).

1 "[...] Whoever shall be found to have committed that incontinence which is against nature" shall be punished, the severity of which depended upon whether the transgressor was a cleric or layperson". (PICKETT, 2002).

2 Também chamadas de psicocirurgias, eram duas técnicas neurocirúrgicas que intentavam eliminar determinadas doenças mentais ou modificar comportamentos inadequados. [...] A técnica determinava 
No Brasil, o Período Colonial foi marcado pela regência das leis da Metrópole, sendo que durante todo esse período a possibilidade de realizar-se o casamento estava intrínseca com a instituição religiosa dominante, ou seja, a católica:

\begin{abstract}
[...] durante todo o período que se estende da Colônia até parte do Segundo Império o casamento era um ato eminentemente controlado pela Igreja, dado o regime de padroado ${ }^{3}[. .$.$] . Naquela época, ainda não havia a separação entre$ Igreja e Estado, como pode ser percebido[...] sobre o que deveria conter no assento de casamento: a igreja ou capela onde o casamento foi celebrado; o nome do padre ou do eclesiástico que assistiu à celebração e uma declaração de impedimento canônico (TUMA, 2017).
\end{abstract}

As leis aqui aplicadas eram decorrentes das Ordenações Afonsinas, Manuelinas e Filipinas, o que, consequentemente, acarretou na transposição territorial da criminalização da homossexualidade para o território nacional, que antes só se aplicava em terras portuguesas. Em tais ordenações, aplicava-se, por exemplo, pena de morte àquele que exteriorizasse a homossexualidade, sendo o condenado queimado. Com a independência em 1822 do Estados Unidos do Brasil e com a elaboração de um Código Criminal em 1830, não se tinha mais normas a respeito à homossexualidade, salvo as leis militares (BOMFIM, 2011).

Finalmente, encerrando a retomada histórica, em 1890, o Marechal Deodoro da Fonseca estabeleceu que o Estado e suas Unidades se separassem das matérias religiosas, dando uma abertura favorável para criação de uma legislação de maior generalidade, possibilitando, enfim, a reflexão acerca da pluralidade social. A respeito do casamento, por meio do Decreto № 181, foi encerrada a sua ligação intrínseca das cerimonias com os dogmas religiosos. Instituiu-se, então, o Casamento Civil com possibilidade de sua anulação e divórcio (TUMA, 2017).

que o paciente deveria ser submetido a uma série de aplicações de eletrochoque, até perder a consciência. Estas aplicações serviam ao mesmo tempo como anestésico e como parte do tratamento. O cirurgião então levantava a pálpebra superior e com o dedo tateava o teto da órbita, procurando localizar o ponto de maior depressão. Neste ponto, tangente ao olho, introduzia uma punção metálico, um objeto pontiagudo semelhante a um picador de gelo (Fig. 4). Para alcançar o cérebro, dava pequenas pancadas com um martelo, fazendo o penetrar a uma profundidade de $7 \mathrm{~cm}$ de modo a atingir o lobo frontal. (MASIERO, 2003).

${ }^{3}$ Inúmeros privilégios administrativos públicos aos indivíduos eclesiásticos. (TUMA, 2017). 
Dessa forma, aproximando-se dos panoramas convenientes de fato com a pesquisa, com a promulgação da Constituição Federal de 1988 ocorreu uma abertura definitiva para uma proteção dos direitos sexuais e de gênero.

Essa abertura que se fala corresponde primordialmente à esfera jurídica por consagrar um rol de princípios fundados na dignidade da pessoa humana, uma vez que ao atentar-se para os pareceres sociais quanto a homossexualidade, ainda se visualiza uma relativa relutância de aceitação dos mesmos quanto entidade familiar.

Com a Constituição Cidadã, em matéria de família, surgiram as famílias monoparentais, abarcou-se devidamente a questão dos filhos tidos fora do casamento, do concubinato, e também instituiu o instituto da união estável desconexo com a necessidade de submete-lo ao casamento para fins de constituir uma família, como era posto anteriormente. Em outras palavras, anteriormente só se era considerado família aqueles que se submetessem à celebração do matrimônio.

A família, na realidade, passou a mostrar suas variedades de arranjos, desvinculando-se das formalidades que traçavam uma maneira singular e estrita de formação de um núcleo familiar, representando, portanto, um relevante instrumento de proteção e promoção da entidade familiar, superando o entendimento da entidade familiar como um núcleo apenas econômico e de reprodução, para um espaço plural, livre, igualitário e, sobretudo, afetivo.

Antônio Moreira Maués assevera, de forma contundente, a respeito disso:

\begin{abstract}
A partir dessas normas constitucionais, tanto a doutrina quanto a jurisprudência passaram a debater quais as novas características do instituto jurídico da família, o que se mostrou necessário para adequar a legislação civil às novas diretrizes. Desse modo, a família deixou de ser caracterizada pela sua forma (no sentido de formalidades fechadas e restritas) de constituição, para se fundamentarem em princípios como a afetividade, a estabilidade e a publicidade, valorizando a pessoa humana mais do que suas relações patrimoniais. (MAUÉS, 2015, p. 145).
\end{abstract}

Assim, com essa nova perspectiva trazida pelos princípios que buscam reger o ordenamento jurídico, a essência da família passou a ser reestruturada juridicamente de forma coerente à nova realidade social, ou seja, considerando as circunstancias trazidas pela divisão do trabalho, desenvolvimento tecnológico, pelas novas concepções acerca de gênero, com as conquistas do movimento feminista, que 
conferiram autonomia às mulheres frente ao ambiente profissional e doméstico, e com a secularização das ideias e dos propósitos da ordem nacional.

Portanto, a finalidade da família deixou de ser fundada nos objetivos justificados pela procriação, nas morais conservadoras e religiosas, na supervalorização da virilidade masculina nas relações domesticas e em uma hierarquização sexista, para ter como fim a efetivação dos princípios da dignidade da pessoa humana, acima de tudo, seguida também pelo princípio de liberdade privada, da horizontalidade das relações e outros.

A essência e o propósito universal de família é a composição relacional segura e favorável ao desenvolvimento individual, em que os sujeitos se estruturam e se formam subjetiva e objetivamente. É um locus de individualização psíquica onde o indivíduo ocupa determinadas funções. A união estável, por sua vez, é caracterizada jurisprudencial e doutrinalmente pela convivência duradoura, pública, continua e laços estabelecidos na intenção de constituir uma família entre os cônjuges. É "uma tentativa desenhar um casamento, com a diferença de não haver o ato civil", havendo, além desses elementos objetivos, um elemento subjetivo base que é a reciprocidade afetiva entre aqueles que compõem a família. (PEREIRA, p. 200-204)

As características citadas anteriormente não são necessárias integralmente para haver a formação da união estável. Exemplo disso é identificado nas considerações de Maria Berenice Dias (2011), onde o requisito de ser uma convivência pública não é seguido por muitos casais gays devido ao preconceito e à vulnerabilidade que ainda os afeta. Dessa forma, cobrar a publicidade em caráter amplo como requisito imperativo é submeter ainda mais esse grupo às ameaças de agressões possíveis.

As famílias homoafetivas são, pois, indivíduos do mesmo gênero que se unem a fim de fomentar conjuntamente suas potencialidades, desenvolvendo mutuamente suas individualidades, seus status financeiros, seus laços afetivos e entre outros. Visam, então, alcançar a felicidade por meio do viver compartilhado, enfrentando as adversidades da convivência, superando-as.

Nas palavras de Maria Berenice Dias, portanto: 
[...] para a configuração de uma entidade familiar, não mais é exigida, como elemento constitutivo, a existência de um casal heterossexual, a prática sexual e nem a capacidade reprodutiva[...]. O fato é que os homossexuais estão assumindo para si a linguagem da ternura e da preocupação sentimental em suas relações amorosas, bem como remodelando padrões de conjugalidade e parentalidade, rompendo, assim, os limites convencionais definidores da instituição familiar. (DIAS, 2011, p. 107-109).

A ADIn. 4.277 reconheceu os casais homoafetivos por meio de uma interpretação extensiva do art. 226, §3º da Constituição Federal, uma vez que aqueles devem ser tratados analogicamente aos últimos. Posteriormente, a Resolução n. 175/2013 do Conselho Nacional de Justiça (CNJ) normatizou a conduta dos cartorários, obrigando-os a realizar o casamento homoafetivo ou facilitar sua conversão em casamento (CNJ, 2017).

Nessa lógica, sustenta Raquel Lage Tuma que:

O casamento entre pessoas do mesmo sexo foi regulamentado por meio da Resolução $\mathrm{n}^{\circ}$ 175, de 14 de maio de 2013, que em seu artigo 1 - resolve que é "vedada às autoridades competentes a recusa de habilitação, celebração de casamento civil ou de conversão de união estável em casamento entre pessoas de mesmo sexo." (TUMA, 2017, p. 165).

Dessa forma, mesmo diante de uma travessia histórica conturbada, de perseguições, de intervenções cirúrgicas invasivas, de não aceitação do direito subjetivo de exercício da sexualidade, da criminalização do afeto discordante ao padrão heterossexista, progressivamente a homossexualidade começou a ser compreendida como uma característica inerente aos sujeitos, assim como a heterossexualidade, e que daquela não se exala negatividades. Pelo contrário, a diversidade sexual há de ser aceita para instituição de uma sociedade harmônica livre de preconceitos, superando as construções hierárquicas injustas e infundadas. Pela ADIn. 4.277, visualiza-se um estopim a nível nacional na superação do estranhamento mediante as famílias homoafetivas.

Trata-se, portanto, do respeito à pluralidade da organização familiar trazida pelo texto constitucional, em que a natureza jurídica do casamento se difundiu não somente como um contrato civil submetido a inúmeras normas para a sua constituição, manutenção ou, mesmo, dissolução, mas, principalmente, como uma instituição social pautada em valores superiores aos que estão previstos no conteúdo 
das leis, como o companheirismo, a solidariedade, a ajuda mútua e, sobretudo, o afeto, possibilitando a abertura do reconhecimento de novos arranjos familiares.

\section{ENTENDENDO A ADIN 4.277 E SEUS DESDOBRAMENTOS}

Anterior à ADIn. 4.277 de 2011, as ações que continham o pedido de reconhecimento da união entre os casais homossexuais não eram nem sequer julgadas em significante parte dos casos. Isso, pois, sob fundamento tecnicista, as autoridades afirmavam não haver possibilidade jurídica no pedido, uma vez que inexistia a previsão legal para esse tipo de demanda. Para essas ações, nem ao menos era feita a resolução de mérito pelo juiz. Portanto, o acesso à justiça aos casais homoafetivos era obstruído devido ao não julgamento da causa por haver um vazio (ou omissão) legislativa, embora seja dever do juiz julgar, em tese.

No entanto, em 2001, foi cometido no Recurso Especial $820475 / \mathrm{RJ}^{4}$ o entendimento de que não há impossibilidade jurídica nos casos de inexistência legislativa, cabendo ao juiz contemplar o caso a fim de resolve-lo. Seguiu-se, nessa mesma linha decisória, outros tribunais do Brasil que se voltaram a reconhecer as uniões homoafetivas. (DIAS, 2011)

Referente à ADIn. 4.277, inicialmente (27 de fevereiro de 2008) ela veio sob vestimenta de Arguição de Descumprimento de Preceito Fundamental (ADPF) 178 a requerimento do Governador do Estado do Rio de Janeiro. Ele impetrou por uma interpretação não discriminatória do Estatuto dos Funcionários Públicos Civis do Poder Executivo do Estado do Rio de Janeiro no tema concernente às famílias homoafetivas:

De qualquer maneira, o ajuizamento da ADI 4277 pelo Procurador-Geral da República, legitimado universal - e, portanto, dispensado da demonstração de pertinência temática para a deflagração do controle abstrato de constitucionalidade dos atos do Poder Público - esvazia essa discussão no

\footnotetext{
4 Processo Civil. Ação Declaratória de União Homoafetiva. Princípio da Identidade Física do Juiz. Ofensa não caracterizada ao Artigo 132, do CPC. Possibilidade Jurídica do pedido. Artigos 1ำ da Lei 9.278/96 E 1.723 E 1.724 do Código Civil. Alegação de lacuna legislativa. Possibilidade de emprego da analogia como método integrativo.
} 


\begin{abstract}
caso em tela. De fato, a ADI 4277, admitida como sucedâneo da ADPF 178 e apensada à presente ação, tem pedido idêntico: a interpretação conforme a Constituição do art. 1723 do Código Civil, de modo a que seja o mesmo aplicável, com os respectivos consectários, às uniões entre pessoas do mesmo sexo. Os efeitos práticos de uma procedência de pedidos serão os mesmos numa e noutra. (BRASIL, 2014, p. 56) (Grifos nossos).
\end{abstract}

A ADIn 4.722, logo, visou trazer pacificidade quanto à matéria, vinculando a decisão com eficácia erga omnes. A partir da técnica de "interpretação conforme a Constituição", o conteúdo do art. 1.723 do Código Civil ${ }^{5}$ passou a extrapolar o texto normativo, abarcando não somente a união estável entre o homem e a mulher, mas também entre pessoas do mesmo sexo. Essa decisão fundamentou-se na proibição da discriminação por entender ser a sexualidade um dos componentes da personalidade dos indivíduos e "serve de raiz aos direitos da personalidade, dentre os quais está o direito à própria identidade, à sua identificação, devendo ela ser, logo, tutelada pelo Ordenamento Jurídico" (BRASIL, 2014, p. 65).

Além disso, a discussão valeu-se da preposição de Kelsen, segundo a qual "o que não estiver juridicamente proibido, ou obrigado, está juridicamente permitido", ressalvando o caráter legitimo da causa. Nessa seara, a procuradoria-geral da República defendeu que o texto legal do art. 226 da Constituição Federal não veda as uniões homoafetiva, utilizando-se da norma geral negativa kelsiana, devendo-se afastar qualquer exegese que venha a cometer discriminações e outras consequências do preconceito aos homossexuais. Propôs-se, pois, o uso da analogia entre o tratamento jurídico para as uniões heteroafetivas às homoafetivas.

Na perspectiva de Luís Roberto Barroso (2011), a decisão deixa patente o panorama pós-positivista e do Direito Constitucional contemporâneo, onde Direito e Ética se entrelaçam. Esse panorama tem base (i) na reentronização dos valores na interpretação jurídica; (ii) no reconhecimento de normatividade aos princípios; e (iii) no desenvolvimento de uma teoria dos direitos fundamentais edificada sobre a dignidade da pessoa humana. Para Streck (2009) essa panorama pós-positivista

5 "Art. 1.723. É reconhecida como entidade familiar a união estável entre o homem e a mulher, configurada na convivência pública, contínua e duradoura e estabelecida com o objetivo de constituição de família". 
enfrenta obstáculos em sua fixação, uma vez que o problema da discricionariedade judicial ainda não foi superado (STRECK, 2009, p. 21).

Diante da forma com que se deu a fundamentação da decisão, é possível verificar que os Ministros não deixam de realizar uma reflexão coerente ao Estado democrático de direito, utilizando-se, por exemplo, do mecanismo de interpretação conforme a Constituição para evitar sobrepor-se aos demais poderes sem, contudo, violar os direitos fundamentais.

Assim, o que leva o Tribunal a compor os votos positivos a respeito da União Homoafetiva são, basicamente, dois núcleos essenciais: (a) as acepções principiológicas contemporâneas e (b) a defesa da legitimidade do Poder Judiciário em decidir a matéria com efeitos vinculantes, as quais serão pormenorizadas na sequência

\section{DAS ACEPÇÕES PRINCIPIOLÓGICAS CONTEMPORÂNEAS}

A utilização dos princípios, segundo teorias contemporâneas ${ }^{6}$, traça possíveis decisões fundadas em uma discricionariedade, num mero convencionalismo e atribuições arbitrárias aos textos legais, resultado de uma teoria da argumentação que toma os princípios gerais como cláusulas de abertura, e não meios de trazer coesão (de coerência) ao ordenamento. Segundo Streck (2009), "a validade (das decisões) é o resultado de determinados processos de argumentação em que se confrontam razões e se reconhece a autoridade de um argumento", tomado pelas teorias da hermenêutica filosófica e integrativa de Dworkin. Para compreender a validade argumentativa da ADIn. 4.722, necessário se faz pormenorizar os princípios elencados na decisão e se estão de acordo com o ordenamento jurídico brasileiro que é fundado nos ideais democráticos de direitos.

O primeiro núcleo de compreensão da fundamentação da ADIn. 4.722 tem base nos novos entendimentos acerca do Princípio da Igualdade, que se desenvolve

\footnotetext{
${ }^{6}$ Lênio Streck (2009) faz referência às teorias procedurais, como a teoria da argumentação que ainda possui domínio no esquema sujeito-objeto.
} 
nas ideias de igualdade formal e material. A igualdade formal nega o estabelecimento de hierarquias entre indivíduos, assim como a existência de vantagens e privilégios. "Todos os indivíduos são dotados de igual valor e dignidade", devendo o Estado agir impessoalmente devido a tal princípio. "A igualdade material, por sua vez, envolve aspectos mais complexos e ideológicos [...]. Não basta equiparar as pessoas na lei ou perante a lei, sendo necessário equipará-las, também, perante a vida" (BARROSO, 2011).

Os entendimentos que traçam novas dimensões ao princípio da igualdade são resultados da superação de que, em sociedade, as pessoas partam naturalmente de condições absolutas de igualdade. Somos iguais na condição de seres humanos, mas desta condição insurgem relações diversas, como a econômica, de gênero, sexualidade, de raça, às quais impõem desigualdades e acabam por deslocar grupos para margens sociais, tornando-os vulneráveis. Destarte, Walter Claudius Rothenburg (2008) e Boaventura Souza Santos (1997) conseguem expressar de forma objetiva essa percepção verticalizada da igualdade:

As pessoas são diferentes 'em sua personalidade e em sua ambição, diferentes em sua condição cultural e sua capacidade de produção economica' [...]. Portanto, igualdade é algo que precisa ser obtido a partir de reinvidicacoes e conquistas e, para tanto, o Direito pode servir de valiosa ferramenta (ROTHENBURG, 2008, p. 78).

[...] uma vez que todas as culturas tendem a distribuir pessoas e grupos de acordo com dois princípios concorrentes de pertença hierárquica, e, portanto, com concepções concorrentes de igualdade e diferença, as pessoas e os grupos sociais têm o direito a ser iguais quando a diferença os inferioriza, e o direito a ser diferentes quando a igualdade os descaracteriza. Este é, consabidamente, um imperativo muito difícil de atingir e de manter (SANTOS, 1997, p. 122).

Para Roberto Barroso (2011), a discussão acerca dos aspectos fáticos ou materiais da igualdade, como a possibilidade de superação da discriminação aos homossexuais por meio de uma desigualdade legal, não estaria em pauta no caso, 
sendo invocado o art. $3^{\circ}$, inciso IV da Constituição ${ }^{7}$ em seu sentido estritamente formal para fazer jus às uniões entre pessoas do mesmo sexo. (BARROSO, 2011, p. 121)

$\mathrm{O}$ Direito presta-se como mecanismo de conquista de tratamentos materiais equivalentes, assegurando a igualdade para além dos muros legais. Assim, contrário do que afirma Barroso (2011), a discussão acerca das Uniões homoafetivas não se exaure no âmbito da igualdade formal da maneira com que foi feita. $O$ aparato jurídico não se constitui apenas da esfera jurisdicional para concluirmos que a decisão, que teve apenas efeitos normativos apenas na atividade dos tribunais, traga, de fato, uma igualdade formal efetiva e, enfim, a igualdade material. A decisão em nada alterou a omissão legislativa, tanto no código civil quanto na própria Constituição Federal. Em que pese ter servido como ação afirmativa, sua força normativa incide sobre as instancias de juízo, sendo que naquelas de maior significância política e apreço das camadas populares a matéria continua silenciada e consentindo com a discriminação material.

Portanto, a dimensão social do princípio da igualdade que proíbe a discriminação no sentido negativo, impondo-se a obrigação de diferenciação ("dever de eliminação ou atenuação, pelos poderes públicos, das desigualdades sociais, econômicas e culturais, a sim de se assegurar uma igualdade jurídico-material"), foi afirmada de modo parcial com a ADIn. 4.722 (ROTHENBURG, 2008, p. 81). O reconhecimento jurídico dos casais homossexuais como merecedores de um tratamento igualitário depende da atividade jurisdicional, que só exala efeitos quando provocada. Porém, a manutenção do vigor dos dispositivos omissos, para quem é preconceituoso e pratica a discriminação, reforça concepções e ideias no sentido de que o ordenamento jurídico em suas instancias majoritárias mantêm-se consentido com o menosprezo à diversidade sexual.

Outro princípio contemplado na decisão foi o da liberdade pessoal, que se desenvolve na autonomia privada. A liberdade pessoal, em sua concepção atual, é o poder de autodeterminação de uma pessoa em meio à diversidade de possibilidades, sendo estas condicionadas pelo contexto sociocultural onde ela se insere. A liberdade

\footnotetext{
7 "Art. $3^{\circ}$ Constituem objetivos fundamentais da República Federativa do Brasil: [...] IV - promover o bem de todos, sem preconceitos de origem, raça, sexo, cor, idade e quaisquer outras formas de discriminação".
} 
sexual, sendo entendida como "a possibilidade de viver sua orientação sexual em todos os seus desdobramentos" pode ser exercida com a superação das normativas fundamentalistas de vertente cristã e dos estudos científicos que tornavam a sexualidade "desviante" uma patologia. A sua prática é reflexo do exercício da autonomia privada, que não ameaça bens alheios para ser proibida.

Ainda acerca do princípio da liberdade, Luís Roberto Barroso (2011) disserta da seguinte maneira:

\begin{abstract}
A imposição de restrições deve ser justificada pela promoção de outros bens jurídicos de mesma hierarquia, igualmente tutelados pela ordem jurídica. Essa é uma exigência do princípio da razoabilidade ou proporcionalidade, mais especificamente do sub-princípio da proporcionalidade em sentido estrito [...]. Ocorre, porém, que o não-reconhecimento das uniões estáveis entre pessoas do mesmo sexo não promove nenhum bem jurídico que mereça proteção em um ambiente republicano. Ao contrário, atende apenas a uma determinada concepção moral, que pode até contar com muitos adeptos, mas que não se impõe como juridicamente vinculante em uma sociedade democrática e pluralista, regida por uma Constituição que condena toda e qualquer forma de preconceito. (BARROSO, 2011, p. 125).
\end{abstract}

O princípio da dignidade humana também é invocado como escudo de tutela do direito homoafetivo, visto que tal grupo é merecedor de igual "respeito e consideração", assim como todos outros indivíduos, sem restrições. É esse princípio que funda o reconhecimento jurídico dos Direito de uma minoria vulnerável socialmente, que recorrem, consequentemente, aos mecanismos Estatais para alcançar a efetivação da segurança jurídica. Segurança, esta, também contida no rol de princípios utilizados na fundamentação da decisão.

Por fim das bases principiológicas, o princípio da segurança jurídica "envolve a tutela de valores como a previsibilidade das condutas, a estabilidade das relações jurídicas e a proteção da confiança." (BARROSO, 2011, p. 128). Logo, o silencio do ordenamento quanto às questões concernentes aos casais de mesmo sexo trazem instabilidade nos atos negociais com terceiros, além de uma imprevisibilidade em sentido amplo quanto aos próprios Direitos, resultado do desconhecimento legal lato sensu dessas uniões. Com o entendimento exteriorizado pela ADIn. 4.722, essa insegurança foi parcialmente cessada, uma vez que a omissão legal ainda existe e reafirma a homossexualidade como grupo juridicamente "deslocado" de uma das mais 
importantes fontes do Direito Brasileiro: a lei stricto sensu, perpetrando, dessa forma, ideais de discriminação no sentido negativo.

\section{DA DEFESA DA LEGITIMIDADE DO PODER JUDICIÁRIO EM DECIDIR A MATÉRIA COM EFEITOS VINCULANTES}

O segundo núcleo de compreensão da decisão é referente à legitimidade do STF em vincular matérias como essa. No mais, o conteúdo tratado pela mencionada ADIn. traz inerentemente a necessidade de fundamentar as técnicas que legalizam o proceder dos votos, seguindo o princípio processual da fundamentação do juiz. Nesse sentido, a defesa da legitimidade do Poder Judiciário em decidir a matéria com efeitos vinculantes, citado como o segundo núcleo essencial da decisão, é o alvo de questionamentos, os quais constituem o motivo fundante da presente e posteriores pesquisas.

Logo, a decisão traz questionamentos quanto a legalidade das técnicas interpretativas utilizadas e seus limites. Questionamentos, estes, que foram previstos pelos próprios Ministros Gilmar Mendes e Celso de Mello ao se defenderem da premeditada acusação de Ativismo Jurídico.

A defesa pontuada e explanada no voto do Ministro Gilmar Mendes, toma como pressuposto que "como todo tipo de linguagem, os textos normativos normalmente padecem de certa indeterminação semântica, sendo passíveis de múltiplas interpretações". Dessa forma, insurge uma incoerência argumentativa nos votos decorrente da propositura de uma interpretação conforme a Constituição do texto do artigo do Código Civil sendo que a própria Lei Maior, em seu art. 226 §3ํ, fazse na mesma formatação do art. 1.723 do $\mathrm{CC}^{8}$.

8 "Art. 226. A família, base da sociedade, tem especial proteção do Estado. [...] § 3ํㅜ Para efeito da proteção do Estado, é reconhecida a união estável entre o homem e a mulher como entidade familiar, devendo a lei facilitar sua conversão em casamento" (BRASIL, 1988).

Art. 1.723. É reconhecida como entidade familiar a união estável entre o homem e a mulher, configurada na convivência pública, contínua e duradoura e estabelecida com o objetivo de constituição de família (BRASIL, 2002). 
Sendo assim, a fim de resolução desse paradoxo, a "interpretação conforme a Constituição" proposta na decisão é conciliada com uma interpretação não restrita da norma constitucional e da norma geral negativa de Kelsen, sob argumentação de que:

\begin{abstract}
A referência constitucional à dualidade básica homem/mulher, no $3^{\circ} \stackrel{0}{\text { do seu }}$ art. 226, deve-se ao centrado intuito de não se perder a menor oportunidade para favorecer relações jurídicas horizontais ou sem hierarquia no âmbito das sociedades domésticas. Reforço normativo a um mais eficiente combate à renitência patriarcal dos costumes brasileiros. [...] A Constituição não interdita a formação de família por pessoas do mesmo sexo. Consagração do juízo de que não se proíbe nada a ninguém senão em face de um direito ou de proteção de um legítimo interesse de outrem, ou de toda a sociedade, o que não se dá na hipótese sub judice. (BRASIL, 2014, p. 3) (Grifos nosso).
\end{abstract}

Além de reforçar que:

[...] o texto, em si mesmo, nessa linha, não é excludente[...] da possibilidade de se reconhecer a união estável entre pessoas do mesmo sexo, não com base no texto legal (art. 1.723 do Código Civil), nem na norma constitucional (art. 226, § $3^{\circ}$ ), mas com suporte em outros princípios constitucionais. (BRASIL, 2014, p. 155) (Grifos nosso).

Na perspectiva posta por Lênio Streck (2009), as argumentações feitas trouxeram à tona novamente $\mathrm{o}$ questionamento de poder existir normas constitucionais inconstitucionais, acarretando na defesa de "bons ativismos judiciais" para solucionar casos que o legislativo demonstra falhas.

Ademais, verifica-se reiteradamente na formação dos votos que a aplicação restrita do dispositivo Constitucional por receio de tomar uma "postura criativa positiva" acarretaria na violação dos preceitos fundamentais da igualdade, da segurança, da liberdade e da dignidade da pessoa humana. Assim, se houvesse havido decisão diversa a que foi feita, incoerente também seria visto que compete ao Tribunal instaurado assegurar a todos a igualdade de oportunidade, "[...] de modo que cada um possa conduzir sua vida autonomamente segundo seus próprios desígnios e que a orientação sexual não constitua óbice à persecução dos objetivos pessoais." (BRASIL, 2014, p. 63). 
Ainda nesse sentido, Barroso reconhece o dever do Tribunal de, frente a uma lacuna legislativa, realizar o preenchimento desses vazios normativos por meio do procedimento de integração. "Na omissão ou lacuna da lei, deve o juiz recorrer à analogia, aos costumes e aos princípios gerais do Direito. Para os fins aqui relevantes, abre-se uma nota acerca dos princípios e da analogia como mecanismos de integração da ordem jurídica." (BARROSO, 2011, p. 134).

As inovações traçadas pela Constitucionalização dos Direitos, onde há um compromisso em superar qualquer tipo de violência que incida sobre a dignidade humana, o papel dos tribunais ganhou maior notoriedade em 'fazer acontecer' os propósitos Democráticos de Direito. Parte-se, então, da premissa de que os juízes possuem uma responsabilidade política e são, por isso, obrigados a obedecer a integridade do Direito para evitar que as suas decisões sejam eivadas de finalidades morais ou puramente políticas (STRECK, 2009).

Questiona-se, pois, a legitimidade e os limites do Poder Judiciário em concretizar demandas sociais, em específico o caso das uniões homoafetivas, uma vez que:

\begin{abstract}
De todo modo, o ponto fulcral não está nem no exegetismo nem no positivismo fático (por todos, basta examinar as teses do realismo jurídico nas suas variadas perspectivas) e tampouco nas teorias que apostam na argumentação jurídica como um passo para além da retórica e como um modo de "corrigir as insuficiências do direito legislado". Na verdade, o problema, em qualquer das teses 20 que procuram resolver a questão de como se interpreta e como se aplica, localiza-se no sujeito da modernidade, isto é, no sujeito "da subjetividade assujeitadora", objeto da ruptura ocorrida no campo da filosofia pelo giro linguístico-ontológico e que não foi recepcionado pelo direito (STRECK, 2009, p. 19).
\end{abstract}

Para compreender então como se dá o devido protagonismo do Poder Judiciário brasileiro, é cabível diferenciar ativismo judicial de judicialização da política, sendo que este último significa "valer-se de mecanismos próprios de decisões judiciais para a resolução de conflitos na seara política" e "envolve o poder judiciário na sua totalidade e é de cunho procedimental" (CARVALHO, 2015).

Tendo o Estado constitucional de direito, em conjunto da jurisdição nacional, ganhado território para uma atuação de maior tutela dos direitos fundamentais e do próprio regime democrático, a teoria da separação dos poderes começou a ser 
revisada, primordialmente pela criação do sistema de freios e contrapesos. A partir disso, a expansão da atividade dos tribunais fez "emergir o fenômeno da judicialização da política, e com ele a transferência dos processos decisórios dos poderes executivo e legislativo para o judiciário" (CARVALHO, 2015, p. 255)

Nesse sentido, a judicialização da política no Brasil é decorrente, principalmente, do amplo acesso aos tribunais por grupos interessados e pela inefetividade das instituições representativas, destacando-se os tribunais como a instancia de concretização de Direitos.

Em tempos passados, a crise do judiciário era resultado da falta de comprometimento da esfera jurisdicional para com a efetivação dos Direitos Sociais, fundada a partir do medo de ferir a esfera da legalidade e toda uma ordem democrática, o que levava os juízes a invocarem um legalismo absoluto em detrimento da profunda reflexão dos direitos fundamentais em jogo (CORREIA, 2003).

Hoje, entretanto, verifica-se uma atuação mais ativa dos magistrados, em que estes não hesitam em fazer uso dos preceitos constitucionais gerais, utilizando-os não só como meio de efetivar demandas sociais, mas que também podem ser utilizados para criar um direito distorcido que fere o sistema de freios e contrapesos, ameaçando de fronte a democracia. É aí que está o malefício. É nesse sentido que se caracteriza a prática de Ativismo Judicial.

[...] não podemos mais aceitar que, em pleno Estado Democrático de Direito, ainda se postule que a luz para determinação do direito in concreto provenha do protagonista da sentença. Isso significa que, para além da cisão estrutural entre casos simples e casos difíceis, não pode haver decisão judicial que não seja fundamentada e justificada em um todo coerente de princípios que repercutam a história institucional do direito. Desse modo, tem-se por superada a discricionariedade a partir do dever fundamental de resposta correta que recai sobre o juiz no contexto do paradigma do Estado Democrático de Direito (STRECK, 2009, p. 19).

Por outro lado, Luís Roberto Barroso (2012) visualiza no Ativismo Judicial uma atitude por vezes necessária para amenizar os descompassos entre a classe política e sociedade civil, não sendo a assimilação da Política com o Direito uma prática de criação de decisões arbitrárias. Para ele, o que se deve evitar é a defesa da autocontenção judicial. 
[...] o ativismo judicial procura extrair o máximo das potencialidades do texto constitucional, sem, contudo, invadir o campo da criação livre do Direito. A autocontenção, por sua vez, restringe o espaço de incidência da Constituição em favor das instâncias tipicamente políticas. (BARROSO, 2012).

Não obstante, as experiências históricas demonstram a instabilidade política e social que a prática do ativismo judicial pode trazer consigo, conforme pode-se verificar nos seguintes casos:

No contexto norteamericano, como nos lembra Christopher Wolfe, em seu The rise of modern Judicial Review, o ativismo judicial pôde nomear desde as posturas conservadoras que perpetuaram a segregação racial e impediram as transformações econômicas que o new deal de Roosevelt tentava operar na primeira metade do século 20 , até as posturas tidas como progressistas ou liberais da Corte de Warren na década de 1960. [...]Na Alemanha, como já afirmamos, a atividade do Tribunal Constitucional Federal também chegou a ser classificada por alguns autores como ativismo judicial, originando a corrente chamada jurisprudência dos valores (de se ressaltar que é exatamente a jurisprudência da valoração que será duramente criticada por Habermas, que a enquadrará como uma postura do poder judiciário que coloniza o espaço público e impede a tomada de decisões pela via democrática). [...] o mais correto é dizer que não há como determinar a "bondade" ou a "maldade" de um determinado ativismo judicial. O mais correto é dizer que questões como essa que estamos analisando não devem ser deixadas para serem resolvidas pela "vontade de poder" (Wille zur Macht) do Poder Judiciário. Delegar tais questões ao Judiciário é correr um sério risco: o de fragilizar a produção democrática do direito, cerne da democracia (STRECK; BARRETO; OLIVEIRA, 2009, p. 4).

Essa preocupação de Streck em dar espaço para Ativismos Judiciais 'bons' resulta que o pedido feito pela PGR por uma Interpretação Conforme a Constituição do art. 1.723 do Código Civil estaria afirmando uma espécie caduca de mutação constitucional que funcionaria, na verdade, "como um verdadeiro processo de alteração forma da Constituição, reservado ao espaço do Poder Constituinte Derivado pela vida do processo de emenda constitucional" (STRECK; BARRETO; OLIVEIRA, 2009, p. 5).

Em suma, para o douto Constitucionalista, os compromissos constitucionais devem ser efetivados por aqueles que a própria constituição delega: o poder constituinte derivado, ou o Congresso Nacional. Caso contrário, se tudo aquilo que não está previsto na Constituição pudesse ser elaborada pelo Poder Judiciário como uma "segunda Constituição", se quer precisaríamos de Constituição. Deixaríamos aos 
quereres do Judiciário para resolver. Cabível seria, então, depender do Poder Legislativo por meio do processo de Emenda Constitucional para solucionar as questões homoafetivas no âmbito do Direito de Família (STRECK, BARRETO, OLIVEIRA, 2009, p. 14).

É sabido, entretanto, que o Poder Legislativo enfrenta uma crise de representatividade, uma vez que os sujeitos políticos, a fim de manterem seu capital político, deixam de tomar partido para evitar de ferir a fidelidade de seus eleitores. No mais, o funcionamento partidário no Brasil demonstra ser frágil, visto não haver "clareza sobre qual é a posição de certo partido sobre temas "fraturantes" (BAHIA, VECCHIATTI, 2013; BARROSO, 2012).

Para doutrinadores como Streck, "ao buscar suprir as lacunas deixadas pelo sistema representativo, o Judiciário apenas contribuiria para a ampliação da própria crise de autoridade da democracia" (NIGRO, 2012). Essa crítica procedimentalista da jurisdição Constitucional desconsidera in casu o fator principal que levou a decisão ser feita como foi: a dificuldade desse grupo minoritário (os homossexuais) em efetivar seus Direitos por meio da via legislativa, uma vez que nela prospera apenas interesses majoritários ou particulares dos Congressistas.

Rachel Nigro (2012), em contraposição as afirmativas de Streck, afirma um campo filosófico rígido para defender a possibilidade de Ativismos Judiciais legítimos, uma vez que toma a linguagem como ação, como mecanismo de constituição do mundo. Nos hard cases, é inerente uma leitura moral da Constituição. Sendo assim, as direções apontadas pelo texto Constitucional não se encerram nele mesmo. Vai além: "considerando a argumentação adotada pelos ministros razoável para justificar suas respectivas decisões, o que me importa destacar é que, contrariando o uso negativo da expressão 'ativismo', a ADPF 132 é um exemplo paradigmático de 'ativismo judicial legítimo'”, cuja fundamentação ideal deveria enfrentar um grande ônus argumentativo por desconsiderar o texto escrito, mas também deveria trazer à tona considerações morais relativas à democracia" (NIGRO, 2012, p.161).

Rachel Nigro, para afirmar a legitimidade do Poder Judiciário no caso, faz-se valer da argumentação principiológica e de uma revisão da teoria da Democracia, tendo em vista os defeitos do sistema representativo.

Tomando Ronald Dworkin (2006) como ponto de partida: 


\begin{abstract}
Um dos lados se declara ardoroso defensor da democracia e ansioso para protegê-la, ao passo que o outro se considera mais sensível às injustiças que a democracia às vezes produz. Mas tal embate continua confuso porque precisa ser visto sob uma luz completamente diferente: não como um debate acerca do grau em que a democracia deve curvar-se perante outros valores, mas sim acerca do que a democracia realmente é (DWORKIN, 2006, apud NIGRO, 2012, p. 164).
\end{abstract}

O entendimento sobre a Democracia trazido por Rachel Nigro (2012) nos permite afirmar que as instancias majoritárias não satisfazem o ideal democrático por si só, logo, o zelo pela Democracia é dado pela interdependência dos Poderes e pela não soberania da maioria, mas sim pelo equilíbrio. Conforme a tese de Dworkin, o limite da jurisdição constitucional não é apenas o texto expresso, mas a manutenção da coerência e integridade do ordenamento por meio da interpretação moral dos princípios envolvidos. Mas isso não significa, porém, que os juízes podem impor suas convicções morais. Nesse sentido, seria "plenamente justificável a atuação de um mecanismo não-majoritário, quando os mecanismos majoritários deixam de dispensar a todos a mesma consideração e respeito" (NIGRO, 2012).

É necessário compreender o jogo político democrático de modo mais complexo. A atuação do Supremo Tribunal Federal (STF) seria como um corretivo dos próprios déficits democráticos. Assim, os direitos fundamentais, quando bem tutelados por uma argumentação coerente, na verdade contribuem para o amadurecimento das discussões políticas e não ameaçam a Democracia. Aliás, tendo sido a questão das uniões homoafetivas "amplamente debatidas pela sociedade brasileira e por diversos órgãos da administração pública e do Judiciário", a sua tutela jurídica tornou-se uma exigência democrática, impossível de ser contemplada pela parcela conservadora existente no legislativo (NIGRO, 2012).

Parcela esta que tem se movimentado de uma forma mais prejudicial ao regime democrático de direito do que de acordo com a sua conservação. Exemplo disso são os projetos legislativos em tramite que obstinam em afirmar que homossexuais não formam família. Um deles é o projeto de decreto legislativo feito pelo Senador Magno Malta (PR/ES). Por meio de um objetivo meramente formal de "Zelar pela preservação da competência legislativa do Congresso Nacional", o projeto iria sustar a resolução do $\mathrm{CNJ}$ que habilitou a celebração de casamento civil, ou de 
conversão de união estável em casamento, entre pessoas de mesmo sexo (SENADO FEDERAL, 2013).

Quando há movimentações positivas quanto à aprovação do reconhecimento legal da união estável entre pessoas do mesmo sexo, como no caso havido pela Comissão de Constituição, Justiça e Cidadania (CCJ) no Senado referente ao PLS 612/2011, efervescem oposições de notório apoio popular que se mostram dispostas a recolocarem a minoria homossexual mais à margem (SENADO FEDERAL, 2017). Verifica-se, então, que ainda existe uma insegurança jurídica e política vivida pelos sujeitos homossexuais que visam formar uma família. Insegurança esta que só seria amenizada pela adequação legal, uma vez que as instituições pátrias têm dado indícios de simpatia à homofobia, conforme Maria Berenice Dias (MAIA, 2018).

Portanto, é possível constatar a intensa controvérsia entre as concepções sobre o ativismo judicial. Enquanto alguns afirmam ser uma prática indevida e que dirige o estado democrático a uma maior crise, outros verificam que é um movimento contemporâneo inevitável pelo qual os sistemas não-autoritários irão se efetivar de forma mais complexa. Enquanto alguns, invocando a proteção da democracia, deixariam de efetivar demandas fundamentais à integridade dos sujeitos homossexuais à espera de um 'devido procedimento democrático', outros contemplam a atuação jurisdicional como parte do processo político e como via legítima de exalar decisões contra majoritárias, mas justas.

No mais, aceitar a existência de um ativismo judicial legítimo não necessariamente significa deixa-lo sobre suas próprias vontades, mas sim assumir a responsabilidade social e jurídica desses personagens. Além do mais, aceitar esse fato é também assumir uma responsabilidade: a de denunciar a atuação judicial duvidosa em suas fundamentações, uma vez que toda instancia está passiva de corruptibilidade.

\section{CONCLUSÃO}

Apesar da decisão tomada sobre a ADIn 4.722 de 2011 ter agradado boa parte dos intelectuais jurídicos, ela também foi alvo de críticas. Essas críticas foram as 
mesmas que fundaram a inquietude que fomentou essa pesquisa. O questionamento traçado e pioneiro foi: a ADIn 4.722 foi ou não uma decisão indevida? Foi uma típica prática de Ativismo Judicial?

Nesse sentido, por meio de uma retomada histórica, ficou pormenorizadamente o que justifica uma atuação jurisdicional de sentido de tutela, de proteção. Durante séculos os sujeitos Homoafetivos foram postos a margem, sendo perseguidos, julgados e mortos por heresia. Foram, também, objetos probatórios de teorias cientificas que buscaram afirmar tais sujeitos como "anormais" ou "doentes", sendo submetidos a intervenções corporais invasivas e extremamente agressivas. Esse processo histórico que violentou os sujeitos homossexuais perdura em forma de migalhas até hoje em dia, seja nas esferas jurídica e política pela omissão, ou por outras instituições por meio da discriminação de fato.São essas migalhas de um histórico de marginalização que a construção argumentativa principiológica da ADIn 4.722 buscou superar através da afirmação de uma igualdade meramente formal.

A partir da ADIn 4.722, foi possível verificar uma atenção fixa e contundente sobre a atuação das cortes brasileiras, principalmente sobre o STF. Essa atenção tem como fim proteger a Democracia, impondo limites ao exercício jurisdicional, uma vez que a postura discricionária dos juízes lhes daria um poder excessivo que ameaçaria a própria Democracia Constitucional. Entretanto, as linhas que separam o Ativismo Judicial da Judicialização da Política são tênues, sendo que tomar aquela como restritamente negativa e esta como um mero resultado inevitável das novas perspectivas constitucionais e da separação dos poderes, não parece garantir ao máximo as potencialidades do processo democrático.

Destarte, perceber a prática do ativismo judicial como um resultado dessa inevitável Judicialização da Política, como escolha de um modo específico e proativo de interpretar a Constituição, expandindo o seu sentido e alcance", torna possível vislumbrar práticas legitimas de Ativismo para efetivar os compromissos Constitucionais, logo, que não ameaçam a Democracia. Reitera-se, ainda, que o funcionamento da Democracia depende não apenas das vias majoritárias, mas também de outras instâncias de poder para potencializar a integração de grupos minoritários no jogo democrático. 
Portanto, a ADIn 4.722 não demonstra ter trazido nenhuma ameaça para a Democracia, muito pelo contrário. A Democracia estava à espera de uma afirmação positiva do ordenamento no sentido de tutelar as Uniões Homoafetivas como entidade familiar. No entanto, a efetivação das demandas homoafetivas não deve estagnar nessa vitória.

A decisão cometida pelo STF trouxe efeitos imediatos a matéria, tutelando os direitos homoafetivos no âmbito jurisdicional analogicamente ao tratamento formal/positivado às uniões entre homem e mulher. Entretanto, a decisão não exclui a necessidade de aprimorar o ordenamento jurídico e mantê-lo coerente com a realidade. A forma com que a redação da Constituição Federal se dá, reitera simbolicamente uma escolha Constituinte que não é a mais devida atualmente. Para superação integral das desigualdades sexuais formais contidas no ordenamento positivo, a fim de evitar que se dê margem para mal-entendidos no âmbito material, uma alteração sobre a fonte primordial do Direito brasileiro deve ser feita.

Entretanto, para maiores elucidações de como isso seria feito, uma pesquisa mais verticalizada sobre Teoria do Estado, Direito Eleitoral e outras áreas se veem necessárias, uma vez que ainda se vive diante uma crise representativa dentro do Poder Legislativo. Na prática, essa crise traz um óbice nos projetos de lei que dizem respeito à diversidade sexual e de gênero. Assim, o tramite de uma proposta de Emenda Constitucional ao parágrafo $3^{\circ}$ do art. 226 da Constituição Federal dificilmente iria ocorrer, por motivos óbvios.

\section{REFERÊNCIAS}

BAHIA, Alexandre Gustavo Melo Franco; VECCHIATTI, Paulo Roberto lotti. ADI N. 4.277 - Constitucionalidade e relevância da decisão sobre união homoafetiva: o STF como instituição contramajoritária no reconhecimento de uma concepção plural de família. Revista de Direito GV, São Paulo, v. 9, n. 1, p. 65-92, jun. 2013.

BARROSO, Luís Roberto. Diferentes, mas iguais: O reconhecimento jurídico das relações homoafetivas no Brasil. Revista Brasileira de Direito Constitucional, n. 17, jan./jun. 2011.

Judicialização, Ativismo Judicial e Legitimidade Democrática. Revista (Syn)thesis, v. 5, n. 1, 2012. 
BRASIL. Constituição da República Federativa do Brasil de 1988. 1988. Disponível em: <http://www.planalto.gov.br/ccivil_03/constituicao/constituicao.htm>. Acesso em: 01 jun. 2018.

Lei no 10.406, de 10 de janeiro de 2002. Institui o Código Civil. 2002. Disponível em: < http://www.planalto.gov.br/ccivil_03/leis/2002/l10406.htm>. Acesso em: 01 jun. 2018.

. Supremo Tribunal Federal. Ação Direta de Inconstitucionalidade 4.277. Relator: Min. Ayres Britto. Publicado em: 14 out. 2014. Disponível em: <http://redir.stf.jus.br/paginadorpub/paginador.jsp?docTP=AC\&doclD=628635> Acesso em: 05 jun. 2018.

BOMFIM, Silvano Andrade Do. Homossexualidade, direito e religião: da pena de morte à união estável. A criminalização da homofobia e seus reflexos na liberdade religiosa. Revista Brasileira de Direito Constitucional, n. 18, p. 71-103, jul./dez. 2011.

CARDIN, Valéria Silva Galdino; CAZELATTO, Caio Eduardo Costa. Da vulnerabilidade social das minorias sexuais sob a perspectiva jurídica. In: CAMPOS, Nilson Tadeu Reis. (Org.). $\mathbf{O}$ direito $\mathbf{e}$ as pessoas vulneráveis na contemporaneidade. Rio de Janeiro: Lumen Juris, 2016.

. Tutela jurídica da sexualidade das minorias sexuais. In: MAZZUOLI, Valerio de Oliveira (Org.). Direitos humanos das minorias e grupos vulneráveis. Belo Horizonte: Arraes, 2017.

; SEGATTO, Antonio Carlos; CAZELATTO, Caio Eduardo Costa Cazelatto. O exercício ilegítimo do discurso de ódio homofóbico sob a ótica da sexualidade e da dignidade humana. Revista Jurídica Unicuritiba, Curitiba, v. 1, n. 46, p. 90-118, 2017. ISSN 2316-753X. Disponível em: <http://revista.unicuritiba.edu.br/index.php/RevJur/article/view/2001/1282>. Acesso em: 04 out. 2018.

CAZELATTO, Caio Eduardo Costa; CARDIN, Valéria Silva Galdino. Das restrições à liberdade de expressão frente à violação dos direitos das minorias sexuais pelo discurso de ódio. Revista Conpedi Law Review, v. 3, n. 2, p. 56-83, dez. 2017. ISSN 2448-3931. Disponível em: <http://portaltutor.com/index.php/conpedireview/article/view/446>. Acesso em: 27 jan. 2018.

Dos impactos do discurso de ódio homofóbico no ambiente informático. Revista de Direito, Governança e Novas Tecnologias, Brasília, v. 3, n. 1 , p. 1-22, jan/jun. 2017. ISSN 2526-0049. Disponível em: $<$ www.indexlaw.org/index.php/revistadgnt/article/view/1947/pdf>. Acesso em: $19 \mathrm{dez}$. 2018. 
Dos aspectos jurídicos da pedofilia: por uma intervenção estatal digna e efetiva ao pedófilo. Revista Quaestio luris, Rio de Janeiro, v. 10, n. 04, p. 2863-2876, 2017. ISSN 1516-0351. Disponível em: <www.epublicacoes.uerj.br/index.php/quaestioiuris/article/view/26686/21927>. Acesso em: 19 dez. 2018.

Homophobic hate discourse in the information society: from the impacts to the balance of the computer environment and to human sexuality. Revista do Direito UNISC, Santa Cruz do Sul, v. 1, n. 51, p. 176-191, jan. 2017. ISSN 19829957.

em: $<$ https://online.unisc.br/seer/index.php/direito/article/view/8742>. Acesso em: 04 out. 2018.

. O discurso de ódio homofóbico no Brasil: um instrumento limitador da sexualidade humana. Revista Jurídica Cesumar - Mestrado, Maringá, v. 16, n. 3 , p. 919-938, set./dez. 2016. ISSN 2176-9184. Disponível em: <periodicos.unicesumar.edu.br/index.php/revjuridica/article/view/5465/2893>. Acesso em: Acesso em: 04 out. 2018.

CARVALHO, Acelino Rodrigues. Legitimidade da Jurisdição Constitucionalizada para a Proteção dos Direitos Sociais: das tutelas coletivas aos coletivos de tutela. 2015. Tese (Doutorado em Direito), Programa de Pós-Graduação em Direito, Universidade do Vale do Rio dos Sinos, Rio Grande do Sul.

CNJ, Conselho Nacional de Justiça. Casamento homoafetivo: norma completa quatro anos. 2017. Disponível em: <http://www.cnj.jus.br/noticias/cnj/84740-lei-sobrecasamento-entre-pessoas-do-mesmo-sexo-completa-4-anos>. Acesso em: 06 set. 2018.

DIAS, Maria Berenice. União Homoafetiva: o preconceito \& a justiça. 5. ed. São Paulo: Revista dos Tribunais, 2011.

ESKRIDGE JUNIOR., William N. A history of same sex marriage. Virginia Law Review, v. 79, p. 1419-1513, 1993. Disponível em: $<$ http://digitalcommons.law.yale.edu/fss_papers/1504/>. Acesso em: 14 jun. 2018.

MAIA, Dhiego. Casais gays antecipam casamento com medo de perder direitos sob Bolsonaro. Folha de São Paulo, 2018. Disponível em: <https://www1.folha.uol.com.br/cotidiano/2018/11/casais-gays-antecipamcasamento-por-temer-retrocesso-em-gestao.shtml>. Acesso em: 07 nov. 2018.

MASIERO, André Luis. A lobotomia e a leucotomia nos manicômios brasileiros. Hist. cienc. saude-Manguinhos, Rio de Janeiro, v. 10, n. 2, p. 549-572, ago. 2003.

NIGRO, Rachel. A decisão do STF sobre a união homoafetiva: uma versão pragmática da linguagem constitucional. Direito, Estado e Sociedade, n. 41, p. 157-183, jul/dez 2012. 
PEREIRA, Rodrigo da Cunha (Org). Tratado de Direito das Famílias. 2. Ed. Belo Horizonte: IBDFAM, 2016.

PICKETT, Brent. Homosexuality. The Stanford Encyclopedia of Philosophy, 2002. Disponível em: <https://plato.stanford.edu/archives/spr2018/entries/homosexuality/>. Acesso em: 02 set. 2018.

ROTHENBURG, Walter Claudius. Igualdade Material e Discriminação Positiva: o Princípio da Isonomia. Novos Estudos Jurídicos, v. 13, n. 2, p. 77-92, jul./dez. 2008.

SANTOS, Boaventura de Souza. Uma concepção multicultural de direitos humanos. Lua Nova, São Paulo, n. 39, p. 105-124, 1997.

SENADO FEDERAL. Aprovado na CCJ projeto que legaliza casamento homossexual. $2017 . \quad$ Disponível em: <https://www12.senado.leg.br/noticias/materias/2017/05/03/aprovado-na-ccj-projetoque-legaliza-casamento-homossexual>. Acesso em: 07 nov. 2018.

Projeto de Lei do Senado $\mathrm{n}^{\circ}$ 612, de 2011 - Casamento homoafetivo. Altera os arts. 1.723 e 1.726 do Código Civil, para permitir o reconhecimento legal da união estável entre pessoas do mesmo sexo. 2011. Disponível em: < https://www25.senado.leg.br/web/atividade/materias/-/materia/102589>. Acesso em: 07 nov. 2018.

Projeto de Decreto Legislativo (SF) $\mathbf{n}^{\circ}$ 106, de 2013. Susta os efeitos da Resolução no 175, de 2013, do Conselho Nacional de Justiça, que dispõe sobre a habilitação, celebração de casamento civil, ou de conversão de união estável em casamento, entre pessoas de mesmo sexo. 2013. Disponível em: $<$ https://www25.senado.leg.br/web/atividade/materias/-/materia/112745>. Acesso em: 07 nov. 2018.

STRECK, Lênio Luiz. O Problema da Decisão Jurídica em tempos Pós-Positivistas. Novos Estudos Jurídicos, v. 14, n. 2, p. 3-26, 2009.

; BARRETO, Vicente De Paulo; OLIVEIRA, Rafael Tomaz de. Ulisses e o canto das sereias: sobre ativismos judiciais e os perigos da instauracao de um "terceiro turno da constituinte". Revista de Estudos Constitucionais, Hermenêutica e Teoria do Direito (RECHTD), v. 1, p. 75-83, jul./dez. 2009.

TUMA, Raquel Lage; MAIA, Carlos Eduardo Santos. Casamento Homossexual: Legalização E Ritual. Revista Espaço e Cultura, n. 38, p. 159-180, jun. 2017. 